\title{
Cognitive Processes
}




\section{INTRODUCTORY PSYCHOLOGY}

This series of titles is aimed at A-level psychology students in sixth forms and further education colleges and those wishing to obtain an overview of psychology. The books are easy to use, with comprehensive notes written in coherent language; clear flagging of key concepts; relevant and interesting illustrations; well-defined objectives and further reading sections to each chapter; and selfassessment questions at regular intervals throughout the text.

\section{Published}

INDIVIDUAL DIFFERENCES

Ann Birch and Sheila Hayward

DEVELOPMENTAL PSYCHOLOGY

Ann Birch and Tony Malim

COGNITIVE PROCESSES

Tony Malim

SOCIAL PSYCHOLOGY

Tony Malim and Ann Birch

PERSPECTIVES IN PSYCHOLOGY

Tony Malim, Ann Birch and Alison Wadeley

\section{Series Standing Order}

If you would like to receive future titles in this series as they are published, you can make use of our standing order facility. To place a standing order please contact your bookseller or, in case of difficulty, write to us at the address below with your name and address and the name of the series. Please state with which title you wish to begin your standing order. (If you live outside the United Kingdom we may not have the rights for your area, in which case we will forward your order to the publisher concerned.)

Customer Services Department, Macmillan Distribution Ltd, Houndmills, Basingstoke, Hampshire, RG21 2XS, England. 


\title{
COGNITIVE PROCESSES
}

\section{Attention, Perception, Memory, Thinking and Language}

\author{
Tony Malim
}

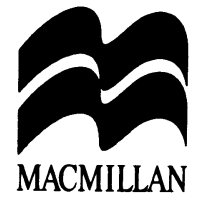




\section{(C) Tony Malim 1994}

Softcover reprint of the hardcover 1st edition 1994

All rights reserved. No reproduction, copy or transmission of this publication may be made without written permission.

No paragraph of this publication may be reproduced, copied or transmitted save with written permission or in accordance with the provisions of the Copyright, Designs and Patents Act 1988, or under the terms of any licence permitting limited copying issued by the Copyright Licensing Agency, 90 Tottenham Court Road, London W1P 9HE.

Any person who does any unauthorised act in relation to this publication may be liable to criminal prosecution and civil claims for damages.

First published 1994 by

THE MACMILLAN PRESS LTD

Houndmills, Basingstoke, Hampshire RG21 2XS

and London

Companies and representatives

throughout the world

ISBN 978-0-333-58811-6 ISBN 978-1-349-13133-4 (eBook)

DOI 10.1007/978-1-349-13133-4

A catalogue record for this book is available from the British Library.

$\begin{array}{rrrrrrrrr}10 & 9 & 8 & 7 & 6 & 5 & 4 & 3 & 2 \\ 03 & 02 & 01 & 00 & 99 & 98 & 97 & 96 & 95\end{array}$

Cartoons by Sally Artz 


\section{Contents}

List of Figures vii

Preface ix

Acknowledgements $\mathbf{x}$

1 Introduction to Cognitive Processes 1

2 Attentional Processes 11

I Selective Attention 11

II Unconscious or Conscious Attentional Processing 22

III Vigilance or Sustained Attention 26

3 Perception 35

I The Physiological Basis for Visual Perception 36

II Sensation and Perception 41

III Theories, Models and Principles 54

IV Visual Illusions 65

V Perception, Learned or Innate? 74

4 Memory Processes 89

I Early Research into Memory 90

II Some Models of Memory 93

III Real Life Memory 117

IV How to Improve Your Memory 125

5 Thinking and Language 137

I What is Thinking? 137

II Thinking as Concept Formation 142

III Problem Solving 149 
vi Contents

IV Language in Relation to Thinking 164

V Language Acquisition 170

Bibliography 180

Index 192 


\section{List of Figures}

2.1 Broadbent's Model of Selective Attention

2.2 Treisman's Attenuation Model of Selective Attention

2.3 Late Filter or Pertinence Model of Selective Attention (Deutsch and Deutsch and Norman)

2.4 Example of a frame similar to those in Schneider and Shiffrin's experiments

2.5 Kahneman's Capacity Model of Attention

2.6 The Relationship between Arousal and Performance (the Yerkes-Dodson Law)

3.1 Diagram Representing the Eye

3.2 The Lens and the Ciliary Muscles 37

3.3 An Illustration of Linear Perspective 43

3.4 Some Monocular Cues to Depth Perception 44

3.5 An Illustration of Shape Constancy 46

3.6 A Number of Ways of Writing the Letter A 49

3.7 The Gestalt Laws of Perception (Proximity) 55

3.8 The Gestalt Laws of Perception (Similarity) 55

3.9 The Gestalt Laws of Perception (Closure) 56

3.10 The Gestalt Laws of Perception (Continuity) 56

3.11 Neisser's Cyclical Theory of Perception 59

3.12 Brunswik's Model of Perception 60

3.13 The Müller-Lyer Illusion $\quad 65$

3.14 An explanation of the Müller-Lyer Illusion (after Gregory, 1968) 66

3.15 The Ponzo Illusion 67

3.16 Circles or Squares Replace Arrowheads in the Müller-Lyer Illusion $\quad 68$

3.17 The Circles Illusion $\quad 69$

3.18 The Necker Cube $\quad 70$

3.19 False Perspective 71

3.20 The Rubin Vase $\quad 72$

3.21 The Poggendorf Illusion 73

3.22 Some Images from Fantz's experiments (1961) 75

3.23 Stimuli used by Maurer and Barrera (1981) 76 
viii List of Figures

3.24 Gibson and Walk's 'Visual Cliff' (1960) 78

3.25 The Horizontal-Vertical Illusion 83

4.1 Flow Diagram Illustrating the Modal Model of Memory 95

4.2 A Hierarchy of Animals 105

4.3 Collins and Quillian's Hierarchical Model of Memory Organisation 106

4.4 The Working Memory Model 110

4.5 Hierarchical Notes on Memory Improvement 132

5.1 An Example of a Hierarchical Tree 153

5.2 A Graphic Representation of the Problem of the Walker $\quad 154$

5.3 A Visual Representation of the Train Problem 155

5.4 A Solitaire Board 159 


\section{Preface}

The aim of this book is to provide an introduction to some of the ways in which psychologists have investigated cognition, and to examine critically some of their more significant findings. The focus is upon cognitive processes, which include attention, perception, memory thinking and language. Chapter 1 provides a brief introduction to cognitive processes and examines some of the methods researchers have used in this area. Chapters 2 to 5 look in turn at attention, perception, memory and finally thinking and language.

As with the rest of the books in this series the intention is to provide a concise framework of comprehensive notes, which may either be used as a basis for further study or for revision purposes. Each chapter begins with objectives to be met and at the end of each section there are self-assessment questions to help independent students test their understanding of the section. Readers are advised to work carefully through the text one section at a time before considering the self assessment questions following it. After further study or reading the questions may be re-examined.

The prime focus of the book is upon GCE A-level and GCSE. It should, however, prove useful to anyone encountering psychology for the first time. This might include students on degree courses, student nurses or midwives, BTEC students and those on teaching courses. I have every confidence that this book will prove to be as useful and popular as the previous titles in this series and above all I hope you will find it enjoyable.

Tony Malim 


\section{Acknowledgements}

The author and publishers are grateful to the following for permission to reproduce illustrations:

Figure 3.12 reprinted with permission from Understanding Psychology by C. B. Dobson, M. Hardy, S. Heyes, A. Humphreys and P. Humphreys, published by Weidenfeld \& Nicolson.

Figure 3.19 reprinted with permission from Art and Illusion by E. H. Gombrich, published by Phaidon Press.

Figure 3.22 reprinted with permission from Child Development: a first course by Kathy Sylva and Ingrid Lunt, published by Basil Blackwell.

Figure 3.23 reprinted with permission from Understanding Children's Development by Peter Smith and Helen Cowie, published by Basil Blackwell.

Figure 3.24 reprinted by permission from page 123 of Psychology (2nd edition) by John Dworetsky, copyright (C) 1985 by West Publishing Company. All rights reserved.

Thanks are due also to Sally Artz who is responsible for the cartoons at the beginning of each chapter. 


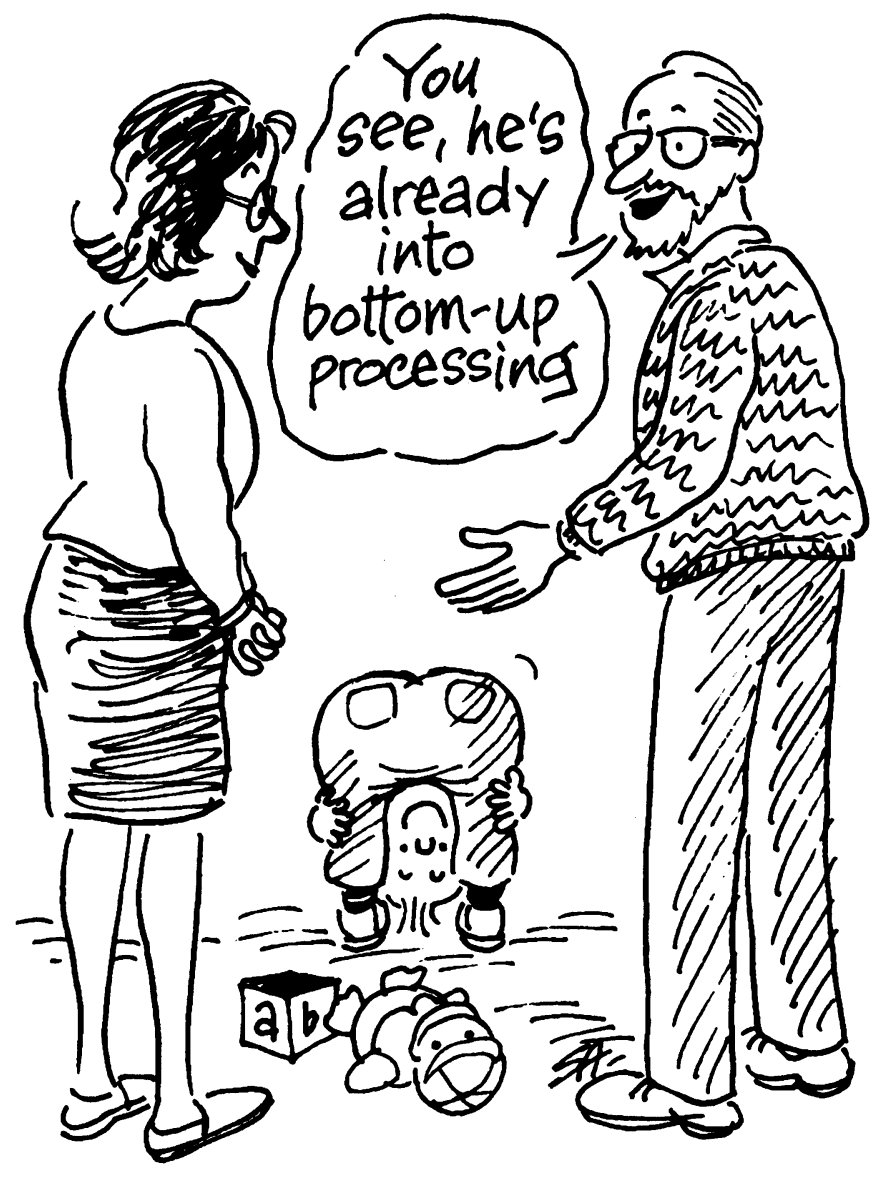

